
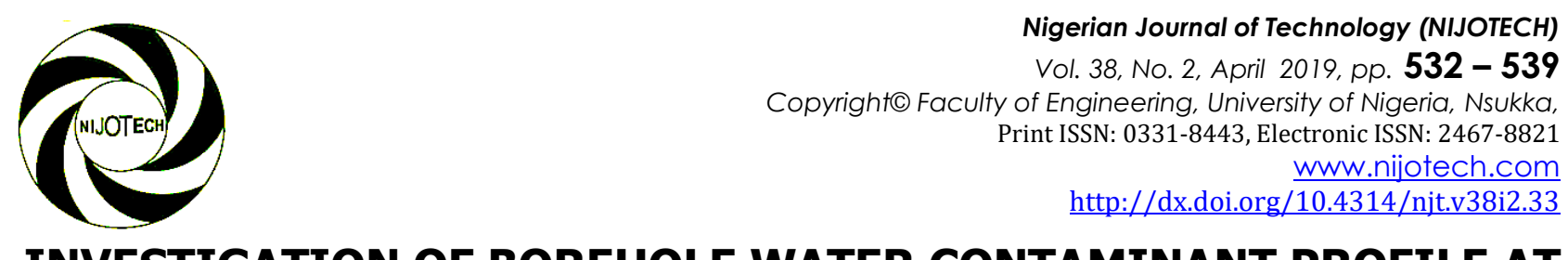

\title{
INVESTIGATION OF BOREHOLE WATER CONTAMINANT PROFILE AT IGWURUTA SOLID WASTE DUMPSITE, RIVERS STATE, NIGERIA
}

\author{
J. N. Ugbebor ${ }^{1, *}$ and B. Ntesat ${ }^{2}$

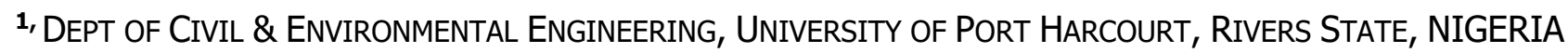 \\ 2, DePt OF AGRicultural \& ENVIRONMENTAL ENGR'G, RiVERS STATE UNIVERSity, PORT HARCOURT, NIGERIA \\ E-mail addresses: ${ }^{1}$ johnugbebor@yahoo.com, ${ }^{2}$ brownson.ntesat@ust.edu.ng
}

\begin{abstract}
This study investigated the boreholes contamination profile at Igwuruta solid waste dumpsite. Physicochemical parameters of the water quality of selected boreholes at various distances were examined, and the results indicated that borehole $A, B$ and $C$ had Total Coliform Bacteria (TCB) of $140.0 \mathrm{cfu} / 100 \mathrm{ml}, 120.0 \mathrm{cfu} / 100 \mathrm{ml}$ and $0 \mathrm{cfu} / 100 \mathrm{ml}$ respectively. Total Heterotrophic Bacteria (THB) threshold of $A, B$ and C indicated $6.0 \times 10^{3} \mathrm{cfu} / \mathrm{ml}, 4.8 \times 10^{3} \mathrm{cfu} / \mathrm{ml}$ and $42 \mathrm{cfu} / \mathrm{ml}$ respectively. The water quality index (WQI) of boreholes A, B and $C$ also indicated 560.82, 475 and 2.6, respectively. The result of borehole $C$ water quality indicated it was excellent and potable for drinking. The WQI obtainable at $A$ and $B$ indicated polluted boreholes due to possible leachate infiltration into the groundwater and proximity of these boreholes to the dumpsite. The study recommended the adoption of solid waste re-use, recycling, and sanitary landfill waste management approach as best practice.
\end{abstract}

Keywords: Coliform, Contaminants, borehole water, dumpsite, Physicochemical, waste

\section{INTRODUCTION}

Many communities have been known to suffer from lack of safe drinking water while many rely on rivers, wells, rain water and boreholes. The coastal areas of Nigeria particularly the Niger Delta Basin, have suffered debilitating environmental degradation and pollution from human activities, manufacturing, and municipal discharges. Urbanization and municipal activities have contributed to the amount of wastes stream generated which results of the contamination in our environment $[1,2]$. Groundwater and surface water quality index monitoring has become a subject of concern in marine, land, and river water due to an uncontrolled disposal of municipal wastes and industrial effluent into the surrounding [3].

Industrial wastes have the potential to introduce strong acid to a water body and may cause debilitating effects on both the fauna and flora [5 - 8]. There have been reports of generation of waste materials and effluents, and their indiscriminate disposal from industries and urbanization. in developing countries which eventually led to deterioration of the water quality in recent years. The generation of municipal and industrial wastes if not well managed will pose problems of contamination of land and water bodies $[6,9,10]$.

The Igwuruta Solid waste dumpsite in Rivers State, was chosen for this study because there have been substantial increase in population growth in the area. Apparently, there are direct discharge of organic and inorganic substances into the site and environs. Water quality is of basic essence to human health and existence as water is essential to sustain life. Access to safe drinking water is one of the oldest public health issues and it's a prerequisite to poverty reduction and prevention of the spread of water borne related diseases $[7,8,11-13]$. Certain criteria must be met for water to be fit for human consumption; odour free, neutral, colourless, zero taste, free from impurity and any form of microorganisms. These water quality indices must be analysed in standard laboratory to prove that it is not contaminated before use. In clean water, certain implicative macro organisms (Aseilus, fly nymphs, worms and aquatic habitats) should be

* Corresponding author, tel +234-803-341-5501 
totally absent [14]. World Health Organization (WHO) and the United Nations (UN) have both recommended a continuous surveillance of water supplies and established targets for water to half the population of people without sustainable access to basic sanitation and safe drinking water by 2020 . Thus, developing strategies and assessing groundwater quality to protect aquifers from contamination are necessary for proper planning and designing of safe drinking water and gradually stop waste dumping practices which may aggravate the risk of groundwater contamination $[8,15]$.

The contamination of groundwater is mainly due to the process of urbanization and industrialization which has progressively developed over time without any regard for environmental consequences [16]. The status of groundwater is a major environmental concern due to the inherent potential public health hazards associated with the use of contaminated water supply. Unconventional dumpsite of waste of all types have been identified and remained a threat to groundwater resources $[17,18]$. This method of waste disposal is the cheapest and oldest means of waste management approach in the third world nations [19-21].

\section{MATERIALS AND METHODS}

\subsection{Study Area}

The Igwuruta solid wastes dumpsite is managed by the Rivers State Waste Management Agency (RIWAMA) located at Ikwerre local government area in Rivers State $\left(4^{0} 57^{\prime} 15^{\prime \prime} \mathrm{N}\right.$ and $\left.7^{\circ} 0^{\prime} 45^{\prime \prime}\right)$ with a population of over 50,000 people [4]. The sampling stations were established at the Igwuruta dumpsite, and nearby boreholes along IgwurutaEneka road, Rivers State. The open dumpsite is enclosed by industrial, commercial and residential buildings. The dumpsite used to be an abandon pit from which construction companies had removed laterites for road construction and in its abandoned state. It was automatically converted to an unlined dump for all manner of wastes ranging from industrial, market, commercial, institutional and domestic wastes. Investigation revealed that the dumpsite was one of the few serving the entire Rivers state.

The selected boreholes were strategic for studies because Igwuruta uses boreholes as a source of water supply.

\subsection{Materials and procedures for water sampling}

The materials for water sampling include

i. $\quad 1$ liter jar bottles and plastic sample containers

ii. Cooler to preserve the sample

iii. Ice blocks

iv. Masking tape

v. Global Positioning System (GPS)

vi. Camera

vii. Odometer

viii. Indelible marker

ix. Standard BOD bottles

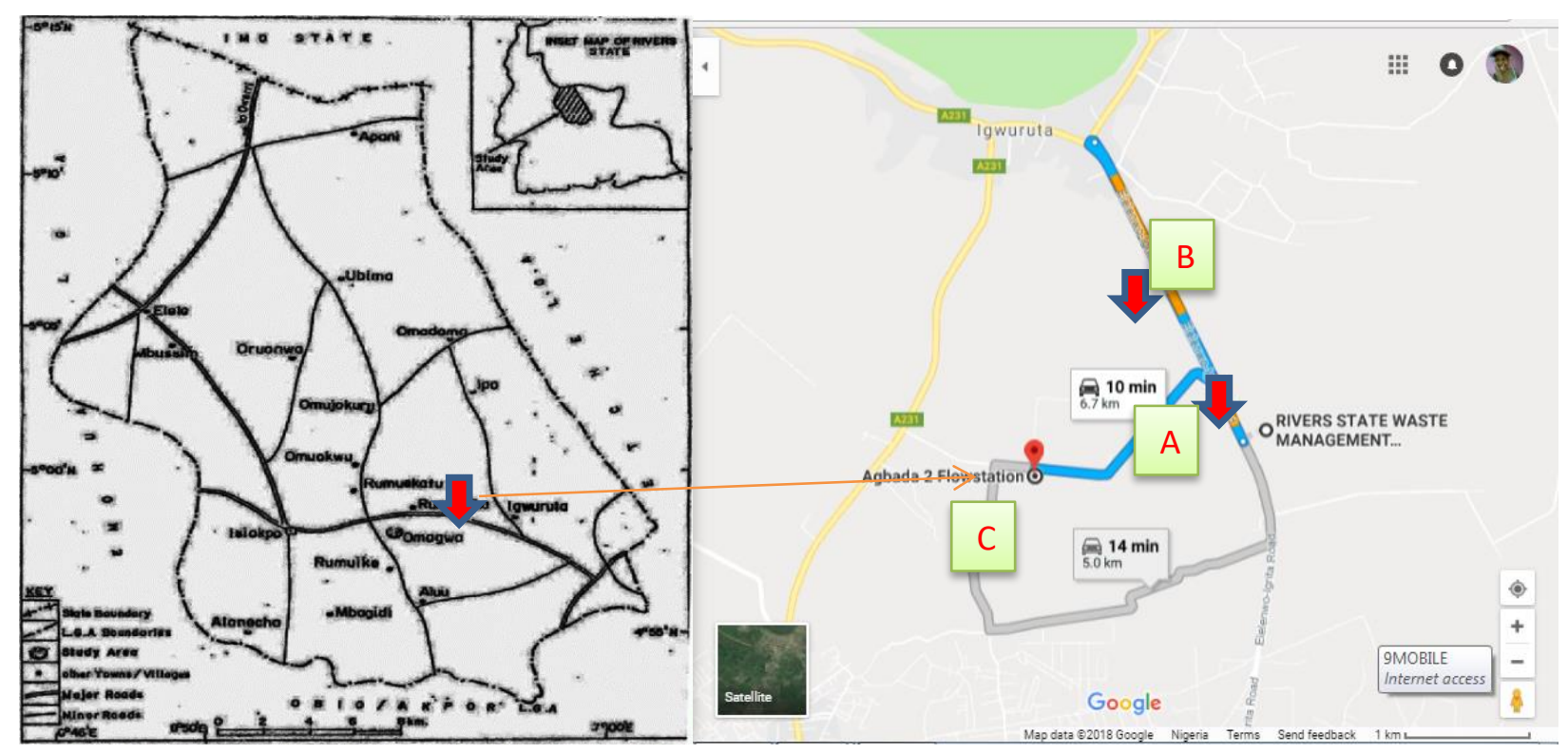

Figure 1: Sampling locations from Dumpsite $(\boldsymbol{A})$, nearby borehole $(\boldsymbol{B})$ and Control (C) Source: https://www.google.com.ng

\subsection{Study design}


This study was designed to use three selected boreholes $A, B$ and $C$ as indicated in Figure 1 as sample stations. The control $C$ is potable drinking water source from Agbada 2 flow station owned by Shell Petroleum Development Company (SPDC) located within the study area. The study evaluated the physicochemical properties, level of trace metals, and influence of leachate on groundwater using weighted arithmetic water quality index in accordance to [22] and [23].

\subsection{Field sample procedures}

Borehole water samples were collected and preserved in an ice chest for analyses in a standard laboratory. The boreholes distances from the dump site were measured with global positioning system (GPS). Biochemical oxygen demand (BOD) and Dissolved oxygen (DO) samples were all collected separately in one liter dark bottles in an air tight condition in order to avoid sunlight penetration. Winkler's method [24] which was applied by adding two drops of freshly prepared starch to $25 \mathrm{ml}$ of the sample and titrated with a $0.0125 \mathrm{ml}$ of sodium thiosulphate to obtain a colourless solution. Standard procedures for water sampling were strictly followed to measure in-stu parameters such as $\mathrm{pH}$, temperature, $\mathrm{EC}$, and colour; while water sample parameters which were not measured on site were carefully taken to the laboratory for analyses.

\subsection{Data analysis}

The physiochemical parameters that were analyzed include Leachate, Total hardness, Colour, Sulphate $\left(\mathrm{SO}_{4}{ }^{2-}\right)$, Phosphate $\left(\mathrm{PO}_{4}{ }^{3-}\right)$, Chemical Oxygen Demand (COD), Biochemical Oxygen Demand (BOD), Dissolved Oxygen (DO), Conductivity, Hydrogen ion concentration $(\mathrm{pH})$, Turbidity, Temperature, Total dissolved solids (TDS), Salinity, and Total Hydrocarbon Content (THC), and heavy metals (Lead, arsenic, Iron and Manganese). The study adopted standard procedures recommended in $\mathrm{HACH} 8051$ and APHA 3111B [25] for water analyses.

Biological parameters such as total coliform and total heterotrophic bacteria counts (THB) were measured in accordance to [26], [27] and [28] to determine the portability of selected sampled borehole water. A tenfold serial dilution was used to arrive at an appropriate dilution of the samples. In the case of THB, aliquots of the established dilutions were plated in duplicates onto the surface of dried sterile nutrient agar platform. Suitable amounts of undiluted water samples were inoculated into a tube of MacConkey Broth medium. All growth media were nurtured at $37^{\circ} \mathrm{C}$ for a period of 24 hours.

\subsection{Water Quality Index}

Water quality index was employed to determine the true status of individual sampling borehole water within and around the dumpsite. This was summarized in Tables 2-5 which showed the water quality rating as per weighted arithmetic water quality index $[22,23]$ using Equation 1-3:

$$
W Q I=\sum \frac{Q i W i}{W i}
$$

Where: WQI = water quality index; Wi is the unit weight for each water quality parameter; $\mathrm{Q} i$ is the quality rating scale for each parameter and was estimated using the Equation:

$$
\begin{aligned}
& Q i=\left(\frac{C i-C o}{S i-C o}\right) \times 100 \\
& W i=\frac{1}{S i}
\end{aligned}
$$

Where: $\mathrm{C}_{\mathrm{i}}=\mathrm{Ca}_{\mathrm{i}}$ and $\mathrm{Cb}_{\mathrm{i}}$ represents the concentration of the nth parameter in the analysed dumpsite borehole water. $C_{0}$ represents the ideal model value of analysed water parameter of the control borehole water taken from the Agbada 2, Shell Petroleum Development Company facility in Igwuruta. $\mathrm{Si}$ represents the allowable standard value of nth parameter which is in accordance with the Nigerian Standard for Drinking Water Quality [27] and the work of [28

\section{RESULTS AND DISCUSSIONS}

\subsection{Results}

Table 1 indicated the physicochemical and bacteriological characteristics of the borehole water as compared to standards of WHO, 2011 and NSDWQ, 2007 limits. These parameters showed an acidic condition, very bad taste, strong odour and high bacteria counts for borehole water A and B. Table 2-5 indicated an average WQI results of the three selected boreholes with contamination indices of dumpsite borehole water A and B. But borehole water C indicated potable drinking characteristics. 
InVestigation of Borehole Water Contaminant Profile at Igwuruta Solid Waste Dumpsite..., J. N. Ugbebor and B. Ntesat

Table 1: Physicochemical and Bacteriological characteristics of the Boreholes

\begin{tabular}{|c|c|c|c|c|c|}
\hline \multirow[t]{2}{*}{$\begin{array}{c}\text { Parameter(s) } \\
\text { /Units/Distance(s) }\end{array}$} & \multicolumn{3}{|c|}{ Borehole water samples } & \multirow[t]{2}{*}{$\begin{array}{c}\text { WHO Limits } \\
2011 \\
\end{array}$} & \multirow[t]{2}{*}{$\begin{array}{c}\text { NSDWQ, } \\
2007 \\
\end{array}$} \\
\hline & $A$ & B & C & & \\
\hline Distance(s) & $10 \mathrm{~m}$ & $630.56 \mathrm{~m}$ & $1500 m$ & & \\
\hline $\mathrm{pH}$ & 5.81 & 6.75 & 6.89 & $6.5-8.5$ & $6.5-8.5$ \\
\hline TDS (mg/l) & 35.30 & 6.30 & $<1.00$ & 600 & 500 \\
\hline Sulphate (mg/l) & $<1.0$ & $<1.0$ & $<1.0$ & 250 & 100 \\
\hline Phosphate (mg/l) & 0.11 & 0.14 & $<0.01$ & - & 0.5 \\
\hline $\operatorname{COD}(\mathrm{mg} / \mathrm{l})$ & 9.00 & 8.00 & $<1.00$ & - & - \\
\hline $\mathrm{BOD}(\mathrm{mg} / \mathrm{l})$ & 3.00 & 2.50 & $<2.00$ & - & - \\
\hline $\mathrm{DO}(\mathrm{mg} / \mathrm{l})$ & 4.97 & 4.40 & 4.18 & - & - \\
\hline $\mathrm{pb}(\mathrm{mg} / \mathrm{l})$ & $<0.001$ & $<0.001$ & $<0.001$ & 0.01 & - \\
\hline As $(\mathrm{mg} / \mathrm{l})$ & $<0.001$ & $<0.001$ & $<0.001$ & 0.01 & - \\
\hline $\mathrm{Mn}(\mathrm{mg} / \mathrm{l})$ & $<0.001$ & $<0.001$ & $<0.001$ & 0.4 & 0.2 \\
\hline $\mathrm{Fe}(\mathrm{mg} / \mathrm{l})$ & $<0.001$ & $<0.001$ & $<0.001$ & 0.3 & 0.3 \\
\hline $\mathrm{THC}(\mathrm{mg} / \mathrm{l})$ & $<1.0$ & $<0.1$ & $<0.1$ & - & - \\
\hline THB (cfu/ml) & $6.0 \times 10^{3}$ & $4.8 \times 10^{3}$ & 42 & 100 & - \\
\hline TCB (cfu/100ml) & 140.0 & 120.0 & 0 & 2 & - \\
\hline Total Hardness (mg/l) & 38.00 & 24.00 & 120.0 & 200 & 200 \\
\hline $\mathrm{EC}(\mu \mathrm{s} / \mathrm{cm})$ & 950 & 850 & 1000 & 1400 & 1300 \\
\hline Odour & very bad & Mild & Odourless & odourless & odourless \\
\hline Taste & very bad & Mild & Tasteless & Tasteless & Tasteless \\
\hline Temperature ${ }^{\circ} \mathrm{C}$ & 26.1 & & & 5 & \\
\hline
\end{tabular}

Table 2: Summary of computed WQI values for sampling location (A)

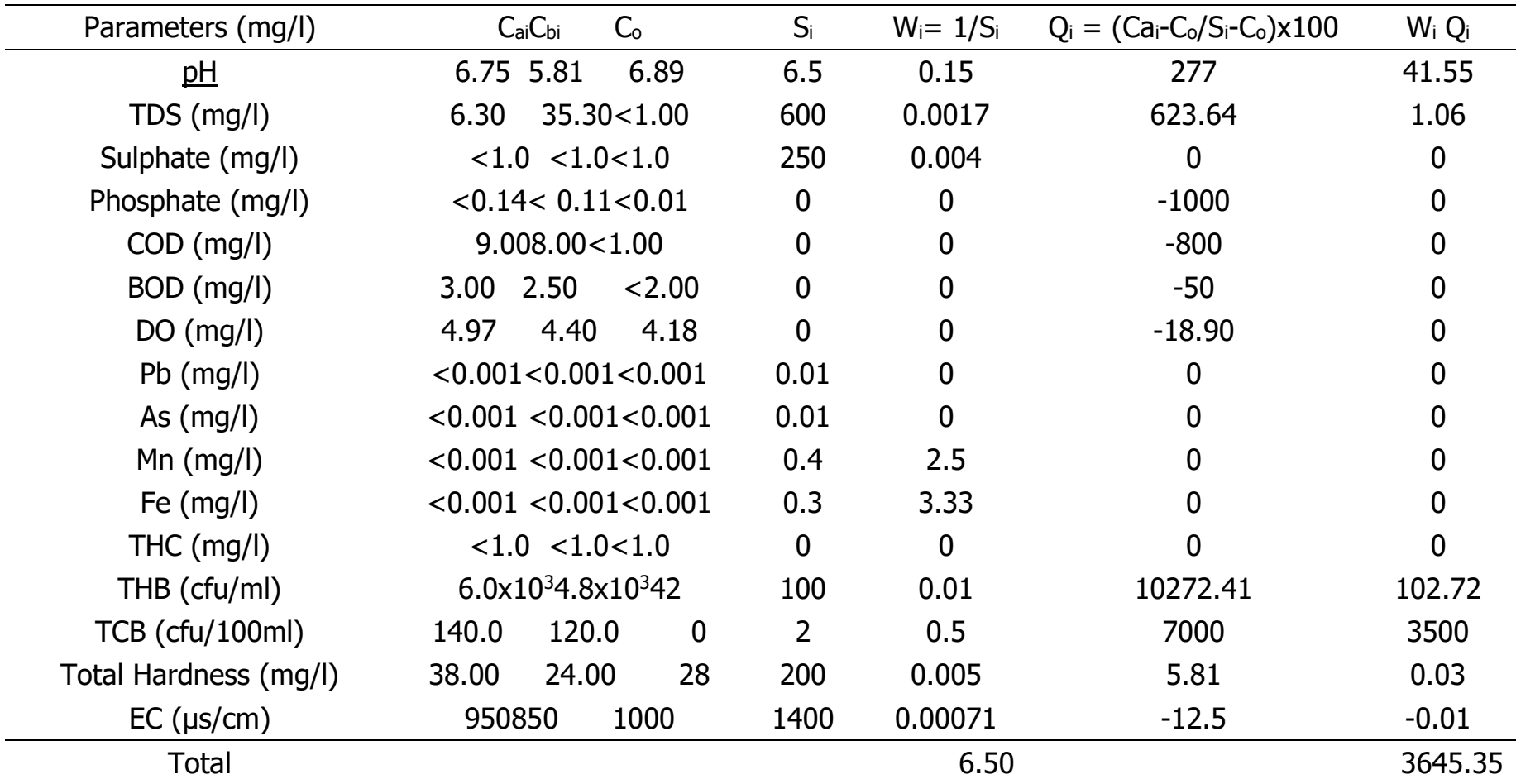


Table 3: Summary of computed WQI values for sampling location (B)

\begin{tabular}{|c|c|c|c|c|c|}
\hline \multirow[b]{2}{*}{ Parameters (mg/l) } & \multirow[b]{2}{*}{$\mathrm{C}_{\mathrm{ai}} \mathrm{C}_{\mathrm{bi}} \mathrm{C}_{0}$} & \multirow[b]{2}{*}{$\mathrm{Si}_{\mathrm{i}}$} & \multicolumn{3}{|c|}{$\mathrm{Q}_{\mathrm{i}}=\left(\mathrm{Cb}_{\mathrm{i}}-\mathrm{C}_{0} / \mathrm{S}_{\mathrm{i}}-\right.$} \\
\hline & & & $W_{i}=1 / S_{i}$ & $\left.C_{0}\right) \times 100$ & $W_{i} Q_{i}$ \\
\hline $\mathrm{pH}$ & $\begin{array}{lll}6.75 & 5.81 & 6.89\end{array}$ & 6.5 & 0.15 & 35.90 & 5.39 \\
\hline TDS (mg/l) & $6.30 \quad 35.30<1.00$ & 600 & 0.0017 & 0.89 & 0.002 \\
\hline Sulphate $(\mathrm{mg} / \mathrm{l})$ & $<1.0<1.0<1.0$ & 250 & 0.004 & 0 & 0 \\
\hline Phosphate (mg/l) & $<0.14<0.11<0.01$ & 0 & 0 & 13 & 0 \\
\hline $\mathrm{COD}(\mathrm{mg} / \mathrm{l})$ & $9.008 .00<1.00$ & 0 & 0 & -700 & 0 \\
\hline $\mathrm{BOD}(\mathrm{mg} / \mathrm{l})$ & $3.00 \quad 2.50<2.00$ & 0 & 0 & -25 & 0 \\
\hline $\mathrm{DO}(\mathrm{mg} / \mathrm{l})$ & $\begin{array}{lll}4.97 & 4.40 & 4.18\end{array}$ & 0 & 0 & 5.26 & 0 \\
\hline $\mathrm{pb}(\mathrm{mg} / \mathrm{l})$ & $<0.001<0.001<0.001$ & 0.01 & 0 & 0 & 0 \\
\hline As (mg/l) & $<0.001<0.001<0.001$ & 0.01 & 0 & 0 & 0 \\
\hline $\mathrm{Mn}(\mathrm{mg} / \mathrm{l})$ & $<0.001<0.001<0.001$ & 0.4 & 2.5 & 0 & 0 \\
\hline $\mathrm{Fe}(\mathrm{mg} / \mathrm{l})$ & $<0.001<0.001<0.001$ & 0.3 & 3.33 & 0 & 0 \\
\hline THC (mg/l) & $<1.0 \quad<1.0<1.0$ & 0 & 0 & 0 & 0 \\
\hline THB (cfu/ml) & $6.0 \times 10^{3} 4.8 \times 10^{3} 42$ & 100 & 0.01 & 8203.45 & 82.04 \\
\hline TC (cfu/100ml) & $\begin{array}{lll}140.0 & 120.0 & 0\end{array}$ & 2 & 0.5 & 6000 & 3000 \\
\hline Total Hardness (mg/l) & $38.00 \quad 24.00 \quad 28$ & 200 & 0.005 & -2.33 & 0.01 \\
\hline $\mathrm{EC}(\mu \mathrm{s} / \mathrm{cm})$ & $950850 \quad 1000$ & 1400 & 0.00071 & 37.5 & 0.03 \\
\hline Total & & & 6.50 & & 3087.50 \\
\hline
\end{tabular}

Table 4: Summary of computed WQI values for sampling location (C)

\begin{tabular}{|c|c|c|c|c|c|}
\hline \multirow[b]{2}{*}{ Parameters (mg/l) } & \multirow[b]{2}{*}{$\mathrm{C}_{\mathrm{ai}} \mathrm{C}_{\mathrm{bi}}$} & \multirow[b]{2}{*}{$\mathrm{Si}_{\mathrm{i}}$} & \multicolumn{3}{|c|}{$Q_{i}=\left(C_{i}-C_{0} / S_{i-}\right.$} \\
\hline & & & $W_{i}=1 / S_{i}$ & $\left.\mathrm{C}_{0}\right) \times 100$ & $W_{i} Q_{i}$ \\
\hline $\mathrm{pH}$ & $\begin{array}{lll}6.75 & 5.81 & 6.89\end{array}$ & 6.5 & 0.15 & 106 & 15.9 \\
\hline TDS (mg/l) & $6.3035 .30<1.00$ & 600 & 0.0017 & 0.17 & 0 \\
\hline Sulphate (mg/l) & $<1.0<1.0<1.0$ & 250 & 0.004 & 0 & 0 \\
\hline Phosphate (mg/l) & $<0.14<0.11<0.01$ & 0 & 0 & 0 & 0 \\
\hline COD (mg/l) & $9.008 .00<1.00$ & 0 & 0 & 0 & 0 \\
\hline $\mathrm{BOD}(\mathrm{mg} / \mathrm{l})$ & $3.00 \quad 2.50<2.00$ & 0 & 0 & 0 & 0 \\
\hline $\mathrm{DO}(\mathrm{mg} / \mathrm{l})$ & $\begin{array}{lll}4.97 & 4.40 & 4.18\end{array}$ & 0 & 0 & 0 & 0 \\
\hline $\mathrm{pb}(\mathrm{mg} / \mathrm{l})$ & $<0.001<0.001<0.001$ & 0.01 & 0 & 0 & 0 \\
\hline As $(\mathrm{mg} / \mathrm{l})$ & $<0.001<0.001<0.001$ & 0.01 & 0 & 0 & 0 \\
\hline $\mathrm{Mn}(\mathrm{mg} / \mathrm{l})$ & $<0.001<0.001<0.001$ & 0.4 & 2.5 & 0 & 0 \\
\hline $\mathrm{Fe}(\mathrm{mg} / \mathrm{l})$ & $<0.001<0.001<0.001$ & 0.3 & 3.33 & 0 & 0 \\
\hline $\mathrm{THC}(\mathrm{mg} / \mathrm{l})$ & $<1.0<1.0<1.0$ & 0 & 0 & 0 & 0 \\
\hline THB (cfu/ml) & $6.0 \times 10^{3} 4.8 \times 10^{3} 42$ & 100 & 0.01 & 42 & 0.42 \\
\hline TC (cfu/100ml) & $140.0 \quad 120.02$ & 2 & 0.5 & 0 & 0 \\
\hline Total Hardness $(\mathrm{mg} / \mathrm{l})$ & $38.00 \quad 24.00 \quad 28$ & 200 & 0.005 & 14 & 0.07 \\
\hline $\mathrm{EC}(\mu \mathrm{s} / \mathrm{cm})$ & $950850 \quad 1000$ & 1400 & 0.00071 & 71.43 & 0.51 \\
\hline Total & & & 6.50 & & 16.90 \\
\hline
\end{tabular}

Table 5: Water Quality classification as per weighted arithmetic water quality index

\begin{tabular}{ccccc}
\hline WQI values & Rating of water quality & Boreholes & WQI values & Grade \\
\hline $0-25$ & Excellent & $\mathrm{C}$ & 2.6 & $\mathrm{~A}$ \\
$26-50$ & Good & & & $\mathrm{B}$ \\
$51-75$ & Poor & & & $\mathrm{C}$ \\
$76-100$ & Very poor & A\&B & $560.82 \& 475$ & $\mathrm{D}$ \\
Above 100 & Not potable for drinking purpose & $\mathrm{E}$ \\
\hline
\end{tabular}

Source: $[22,23]$ 


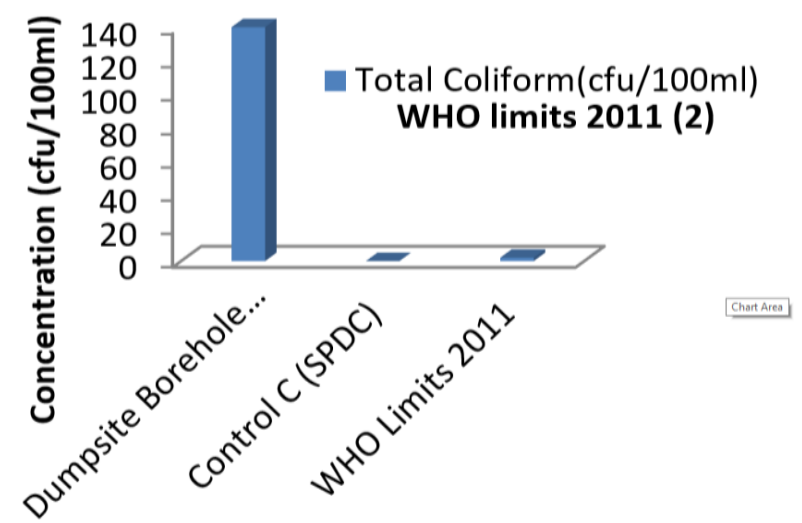

Figure 2: TCB contamination level of dumpsite borehole $A$

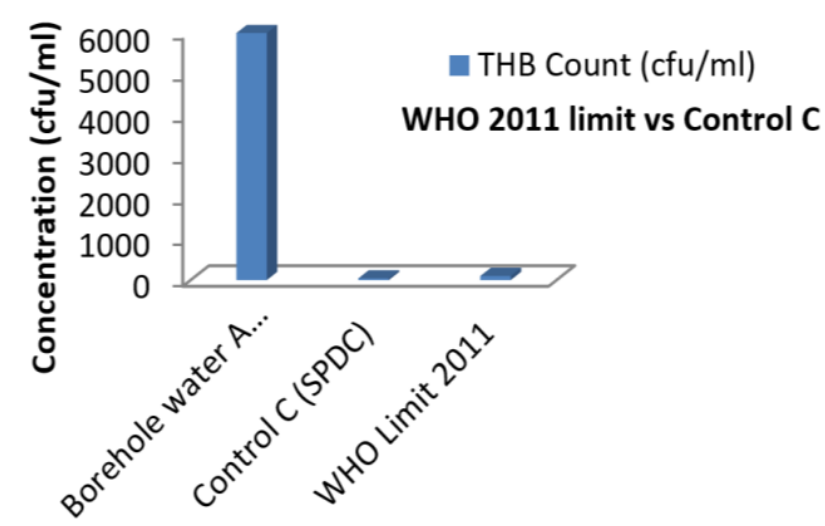

Figure 4: THB contamination level of dumpsite borehole $A$

\subsection{Discussions}

Table 1 showed that the $\mathrm{pH}$ of the groundwater was acidic with a threshold of 5.81 which was below the [27] and [26] limits of 6.5-8.5 for potable water. This illustrated the acidic condition of the groundwater. The implication of high acidity to human health include birth defects, hormone imbalance and skin reactions. Furthermore, acidic condition can result in the corrosion of construction equipment and apparatus; which may cause internal corrosion of pipe systemsmetals and concrete materials [29].

In situ observations, revealed that the borehole water sample from A had a very bad taste, strong odour, and the workers on site made submission that the research body should urgently draw the attention of the government on the position of the groundwater, considering the fact that they could no longer use the water for any meaningful purpose. The water sample from borehole $B$ was observed to be mild in taste and odourless. The analysed parameters were within the permissible limits of standards used in the course of this study [26] and [27] standards. See Table 1).

The bacteriological parameters of the sampled boreholes as reported in Figures2-5, established that

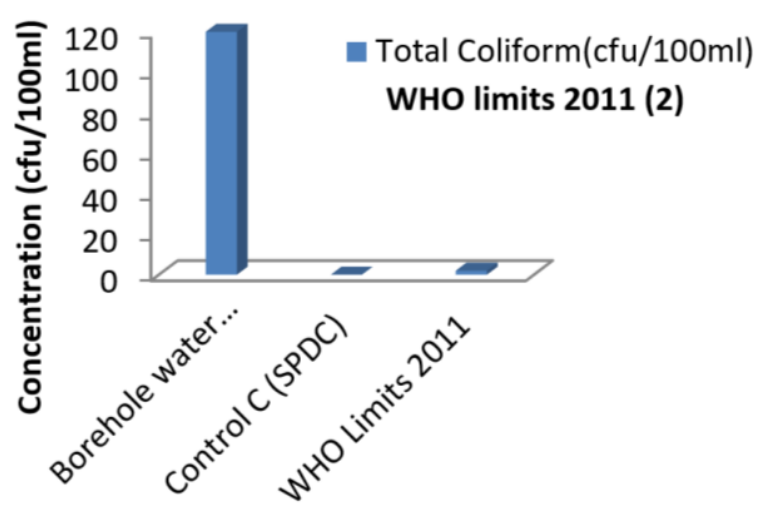

Figure 3: TCB contamination level of borehole $B$ nearest to dumpsite

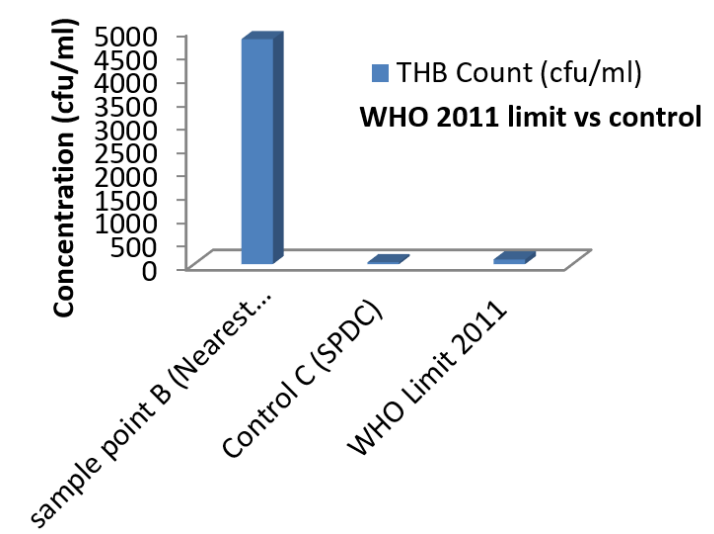

Figure 5: THB contamination level of borehole $B$ nearest to dumpsite

THB and Total coliform bacteria (TCB) were at the threshold of THB $6.0 \times 10^{3} \mathrm{cfu} / \mathrm{ml}$ at dumpsite point $A$ and $4.8 \times 10^{3} \mathrm{cfu} / \mathrm{ml}$ from sampling point $B$ respectively. TCB was $140.0 \mathrm{cfu} / 100 \mathrm{ml}$ at dumpsite sampling station $A$ and $120.0 \mathrm{cfu} / 100 \mathrm{ml}$ at station $B$ respectively. This was high when compared with the WHO and NSDWQ limits of $0-2 \mathrm{cfu} / \mathrm{ml}$.

From Tables 2-4, the average water quality with respect to the calculated quality indices for dumpsite boreholes A, B and C (control) samples were 560.82, 475 and 2.6 respectively. From these estimated average water quality indices, the water quality from dumpsites boreholes A and B are rated not potable for drinking purpose (grade E) (see Tables 2-5). Sample from borehole $\mathrm{C}$ was rated excellent (grade A) (see Tables 4-5). Thus, water sample from borehole $C$ (Agbada 2) flow station at Igwuruta was rated as better quality to that from boreholes $A$ and $B$. However, the study indicated that the borehole $A$ at dumpsite and nearby borehole $B$, are impacted by the waste dump site. This was evident in the quality of water samples obtained at these two borehole stations. Consequently, boreholes A and B water status indicated a possible leachate infiltration and 
contamination into the ground water table. Invariably, this might have resulted in the presence of odour, colour, and taste observed in the water samples from the boreholes $A$ and $B$. Thus, the findings from the three borehole samples agreed with that of [30] which studied the water quality of boreholes and wells from Wukari town in Taraba State, Nigeria. The result from the study agreed with the findings of [31], who did similar work on different sources in the Niger Delta region. Generally, the greater the distance between a source of contamination (dumpsite) and a groundwater source (borehole), the more likely that natural processes such as adsorption, filtration and water purification will gradually eliminate the impact of the dumpsite contamination [32]; [33]; [34].

\section{CONCLUSION AND RECOMMENDATION}

The water quality of the boreholes within and around the Igwuruta dumpsite was evaluated using three different boreholes at significant distances from the landfill. This was carried out with the motive of establishing the degree of pollutant characteristics of the groundwater attributed to improper management of dumpsites. The weighted arithmetic water quality index served as statistical instrument for rating water quality of the sampled boreholes (Table 5).

The study concluded that the borehole water within and nearby Igwuruta dumpsite were laden with bacteria and total coliform. It could be inferred from these results that THB and TCB thresholds have systematically contaminated the borehole water within the period of study. From Table 5, the average water quality indices from Igwuruta boreholes $A$ and $B$ were rated not potable for drinking (grade $E$ ) and borehole $C$ was rated excellent (grade $A$ ).Therefore, with these indices, the study concluded that the borehole water at the dumpsite and the one nearest to it were not fit for consumption until they undergo adequate water treatment. In this light, Igwuruta community which uses the water for domestic purpose should endeavor to thoroughly boil the water and/or subject the water to other treatment approaches.

\section{ACKNOWLEDGEMENT}

The authors wish to express sincere thanks to all those who contributed to this unique research and whose works served as reference literature during this study. Special thanks go to the staff of Phelps International Limited, especially Umoru Christopher for the laboratory works.

\section{REFERENCES}

[1] Onojake, M. C. and Frank, O. "Assessment of heavy metals in a soil contaminated by oil spill: a case study in Nigeria". Chem Ecol., 29(3): 246254, 2013.

[2] Onojake, M. C., Sikoki, F. D., Omokheyeke, O. \& Akpiri, R. U. "Surface water characteristics and trace metals level of the Bonny/New Calabar River Estuary, Niger Delta, Nigeria". Applied Water Science, DOI 10.1007/s/3201015-0306-y. Retrieved on $12 / 1 / 2018$.

[3] Onojake, M. C., Ukerun, S. O. \& Iwuoha, G. "A statistic approach for evaluation of the effects of industrial and municipal wastes on Warri Rivers, Niger Delta, Nigeria". Water Quality Expo Health, 3, pp. 91-99, 2011.

[4[ Owei, O. B., Ede, P. N., Obinna, V. C. \& Akarolo, C. I. "Land market distortions in Nigerian Cities and Urban sprawl: The case study of Abuja and Port Harcourt". $44^{\text {th }}$ ISOCARP Congress, Dalin, China, 19-23; 2008.

[5] Ugbebor, J. N. "Modelling the variation of water quality of the Oshikalake" PhD thesis, Department of Civil Engineering, University of Nigeria, Nsukka, March, 2011.

[6] Ugbebor, J. N., Agunwamba, J. \& Amah, V. E. "Determination of re-aeration Coefficient K2 for polluted stream as a function of depth, hydraulic radius, temperature and velocity" Nigerian Journal of Technology, Vol. 31(2) 174-180, 2012.

[7] Onyinloye, A. "Analysis of the water quality characteristics of Intawaogba creek" A project topic in partial fulfillment for the award of Bachelor's degree in Environmental Engineering. University of Port Harcourt, Nigeria. 2015.

[8] Okparanma, R. N., Jumbo, R. B. and Chukwu, F. $\mathrm{N}$. "Combined effects of municipal and industrial wastes on the quality of the new Calabar northern River, Nigeria" Int. J. Water Res. Environ. Eng. Vol. 8(8): 103-112. 2016.

[9] Akaninwor, J. O., Anosike, E. O. and Egwim, O. "Effect of indomie industrial effluent discharge on microbial properties of new Calabar River" Sci. Res. Essay. 2:001-005, 2007.

[10] Sulphey, M. M. "Introduction to Environment Management" (2 ${ }^{\text {nd }}$ Edition). Published by PHI learning private limited, Delhi, India. Pp 101. 2013.

[11] Gomez, J. D. and Naket, A. C. "Community participation in water and sanitation" International water resources Association, Water International, vol. 27(3): 343-353, 2002. 
[12] United Nations International Children Emergency Fund, UNICEF (2005): National Rural Water Supply and Sanitation Investment Programme. Final draft, Pp.1.

[13] Cosgrove, W. J. \& Rijsberman, F. R. (2000). World water vision: making water everybody's business. Earthscan Publication Ltd., UK, 108.

[14] Eja, M. E. "Water Pollution and Sanitation for Developing Countries"; Sea print (Nig.) Co., Calabar. Pp 185, 2002.

[15] Francis, S., Sidney, N. and Betty, N. "Evaluation of nematode Parasitemia in Oreochromisniloticus from lower new Calabar River, Port Harcourt" Niger Delta, Nigeria. Int. J. Sci. Res. Environ. Sci. 1:263-267, 2013.

[16] Longo, F. O., Balogun, M. R. "Groundwater quality assessment near municipal landfill, Lagos, Nigeria" Research J. of Applied Sci. Eng. Technol, Vol. 2(1): 39-44. 2010.

[17] Fatta, D., Papadopolous, A., Loizidou, M. A study on the landfill leachate and its impact on the groundwater quality of the greater area. Environ. Geochem. Health Vol. 21(2): 175-190, 1999.

[18] Agency for Toxic Substances and Disease Registry (ATSDR) "White Swan Cleaners/Sun Cleaners Area Groundwater Contamination" Wall Township, Monmouth County, New Jersey. 2007.

[19] El-fadel, M., Findikakis, A. N. and Leckie, J. O. "Environmental impacts of solid waste landfilling" J. Environ. Manage. Vol. 50(1): 1-25. 1997.

[20] Daskalopolos, E., Badr, O., and Probert, S. D. "An integrated approach to municipal solid waste management" Res. Cons. Rec. Vol. 24(1): 33-50, 1998.

[21] Jhamnani, B., and Singh, S. K. "Groundwater contamination due to Bhalaswa landfill site in New Delhi" Int. J. Environ. Sci. Eng. Vol. 1(3): 121-125, 2009.

[22] Odia, M., and Nwaogazie, I. L. "Multivariate Statistical Approach in Modeling Surface and Groundwater Quality near Municipal Solid Waste Dumpsites in Warri Metropolitan City" Archives of Current Research International, Vol. 8(4): 1-21, 2017.

[23] Nwaogazie, I. L., Osamudiamen, O. P. and Bovwe, O. "Modeling Groundwater Quality Index Based on Sensitivity Analysis for wet and Dry Seasons in Obio/Akpor Local Government Area,
Rivers State, Nigeria" Nigerian Journal of Technology, Vol. 37(3): 799-805, 2018.

[24] Bryan, J. R., Riley, J. P., Williams, P. J. and Le, B. "A Winkler procedure for making precise measurement of oxygen concentration for productivity and related studies" Journal of Experimental Marine Biology and Ecology, Vol. 21(3): 191-197, 1976.

[25] American Public Health Association (APHA) "Standard method for Examination of Water and Wastewater" APHA, Washington, D. C. 2006.

[26] World Health Organization (WHO) "Guidelines for drinking-water quality" Incorporating First Addendum. $3^{\text {rd }}$ ed. World Health Organization: Geneva. 2011.

[27] NSDWQ Nigerian Standard for Drinking Water Quality "Nigerian Industrial Standards (NIS 554)" Standard Organization of Nigeria. 30, 2007.

[28] Obire, O. and Wemedo, S. A. "The effect of oilfield wastewater on the microbial populations of soil in Niger Delta" Biologia, Vol. 1, 77-85, 1996.

[29] Bromssen, V. U. "Acidification and drinking watergroundwater" In: Acidification and its policy implications, 251-261. Elsevier, Amsterdam. 1986.

[30] Oko, J. O., Aremu, M. O., Odoh, R., Yebpella, G. and Shenge, G. A. "Assessment of water quality index of borehole and well water in Wukari Town Taraba State, Nigeria" Journal of Environment and Earth Science, Vol. 4(5):1-9, 2014.

[31] Etim, E. E., Odoh, R., Itodo, A. U., Umoh, S. D., and Lawal, U. "Water Quality Index for the Assessment of Water Quality from Different Sources in the Niger Delta Region of Nigeria" Frontiers in Science. Vol.3, No.3, pp. 89-95, 2013.

[32] United State Environmental Protection Agency (USEPA) "Getting up to speed: Groundwater Contamination. Wellhead protection: A Guide for small Communities" Chapter 3. EPA/625/R93/002. 1993.

[33] Akinbile, C. O. Environmental impact of landfill on groundwater quality and agricultural soil in Akure Nigeria. Pacific Journal of Science and Technology, 12(2):488-497, 2011.

[34] Udeh, N. U. and Ugbebor, J.N. "Assessment of groundwater quality near a dumpsite (a case study of Ruowhha-EnekaObio/Akpor LGA., Rivers State" $2^{\text {nd }}$ International c water. Pp.1. 2013. 